\title{
Implementasi Sekolah Ramah Anak untuk Membangun Nilai-Nilai Karakter Anak Usia Dini
}

\author{
Tri Na'imah ${ }^{1}$, Yuki Widyasari², Herdian ${ }^{3}$ \\ Program Studi Psikologi, Fakultas Psikologi Universitas Muhammadiyah Purwokerto ${ }^{1}$ \\ Program Studi Pendidikan Anak Usia Dini, FKIP, Universitas Muhammadiyah Purwokerto ${ }^{2}$ \\ Program Studi Psikologi, Fakultas Psikologi Universitas Muhammadiyah Purwokerto ${ }^{3}$ \\ DOI: $\underline{10.31004 / \text { obsesi.v4i2.283 }}$
}

\begin{abstract}
Abstrak
Tujuan penelitian adalah mengkaji implementasi sekolah ramah anak di TK 'Aisyiyah di Purwokerto dan mengembangkan konsep sekolah ramah anak berbasis nilai-nilai karakter anak. Pendekatan penelitian menggunakan pendekatan grounded theory. Subjek penelitian guru dan kepala sekolah TK 'Aisyiyah 1 Purwokerto, TK 'Aisyiyah Teluk Purwokerto Selatan dan TK Bantarwuni, Sumbang. Metode pengumpulan data menggunakan wawancara dan observasi. Analisis data menggunakan analisis komparatif konstan. Hasil penelitian menunjukkan ada tiga kategori dengan lima sub kategori yang berkaitan dengan implementasi sekolah ramah anak di Taman Kanak-kanak untuk mengembangkan karakter anak, yaitu kategori persiapan, perencanaan, pelaksanaan. Taksonomi konsep sekolah ramah anak adalah school-based character education, safe school environment, friendly school, inclusive school, religous school. Implikasi pembelajaran ramah anak adalah dengan menerapkan pembelajaran inklusif, pembelajaran ramah lingkungan, pendidikan sosial, pendidikan berbasis keadilan dan pendidikan berbasis agama.
\end{abstract}

Kata Kunci : sekolah ramah anak; nilai-nilai karakter; anak usia dini

\begin{abstract}
The objectives of the study are assessing the implementation of child-friendly schools in kindergarten' Aisyiyah in Purwokerto, and developing the concept of child-friendly schools based on the character values of children. The research approach uses a grounded theory approach. Subjects were teachers and principals of Kindergarten' Aisyiyah 1 Purwokerto, Kindergarten' Aisyiyah Teluk, South Purwokerto, and Kindergarten Bantarwuni, Sumbang. Data collection methods using interviews and observation. Data analysis uses constant comparative analysis. The results showed there are three categories with five sub-categories related to the implementation of child-friendly schools in kindergartens to develop children's character, namely the categories of preparation, planning, implementation. The taxonomy of the concept of child-friendly schools is school-based character education, safe school environments, friendly schools, inclusive schools, religious schools. The implication of childfriendly learning is to implement inclusive learning, environmentally friendly learning, social education, justice-based education, and religious-based education.
\end{abstract}

Keyword : child-friendly school; character value; early childhood

Copyright (c) 2020 Tri Na'imah, Yuki Widyasari, Herdian

$\triangle$ Corresponding author:

Email Address : trinaimah@ump.ac.id (Jl. Raya Dukuh Waluh PO Box 202 Purwokerto)

Received 22August2019, Accepted 3February 2020, Published xxFebruary 2020 


\section{PENDAHULUAN}

Wacana pendidikan karaktermerupakan upaya menjawab kritik bahwa pendidikan gagal mengintegrasikan pengetahuan dalam perilaku kebajikan (Abu, Mokhtar, Hassan, \& Darmanita Suhan, 2015). Pendidikan karakter merupakan bentuk pendidikan moralitas yang lebih modern dan terpisah dari pendidikan agama (Watz, 2011).

Beberapa penelitian membuktikan bahwa pendidikan karakter pada anak usia dini dapat dilakukan dengan berbagai metode dan pendekatan. Karakter sopan, kreatif, pemaaf, pemberani, kerja sama, kreatif, pemberani, disiplin dan kerja keras dapat diinternalisasi melalui konten cerita fabel untuk anak (Juanda, 2019). Karakter juga dapat diinternalisasi melalui model pembelajaran model pembelajaran BCCT (Beyond Centers and Circle Time)(Iswantiningtyas \& Wulansari, 2019). Guru juga menginternalisasi pendidikan karakter dalam pendidikan agama melalui kegiatan beribadah dan menjalin hubungan sosial yang baik dengan sesama (Abu et al., 2015).

Tetapi pembentukan karakter di sekolah sebaiknya dilakukan melalui pendidikan karakter secara konseptual di semua program pengajaran, dan kemudian diikuti dengan praktik. Oleh karena itu sekolah harus memiliki program untuk mengembangkan karakter secara kompehensif.

Permasalahnnya, belum semua sekolah khususnya Taman kanak-kanak di wilayah Purwokerto memiliki program pendidikan karakter secara komprehensif, sehingga masih ditemukan gejala masalah menurunnya moral anak yang semakin mengkhawatirkan. Kejujuran, kebenaran, keadilan, tolong menolong, dan kasih sayang sudah tertutup oleh penyelewengan, penipuan dan penindasan antar sesama (Nata, 2010). Guru juga merasa gagal mengembangkan nilai-nilai karakter, seperti hubungan sosial, kejujuran, dan disiplin (Abu et al., 2015).

Fenomena tersebut membuktikan bahwa bagi beberapa anak, sekolah tidak selalu memberikan pengalaman yang positif. Beberapa anak mengalami kondisi yang kurang menyenangkan, mengalami pelecehan atau kekerasan. Kondisi ini tidak kondusif untuk belajar atau berkembang, dan seharusnya tidak ada anak yang mengalaminya. Oleh karena itu dibutuhkan sekolah yang dianggap "ramah anak", karena perlindungan anak dalam pendidikan formal menjadi penting, karena anak mempunyai hak untuk dilindungi secara fisik maupun psikologis.

Konsep sekolah ramah dikembangkan berdasarkan teori konstruktivisme sosial Vygosky yang mengatakan bahwa sekolah yang efektif dalah jika memberi kesempatan anak berinteraksi dengan teman dan gurunya untuk mengkontruksi pengetahuan dan pengalaman baru (Ekemezie \& Chinasa, 2015). Sekolah ramah anak merupakan upaya perbaikan organisasi sekolah yang menekankan pada kesehatan fisik dan mental anak-anak serta memberikan perhatian lebih pada akses pendidikan, pemerataan dan kualitas. Oleh karena itu, peran guru di sekolah ramah anak memiliki kendali penuh atas anak dan lingkungan untuk menciptakan lingkungan belajar yang tepat, tanpa kekerasan, pelecehan dan menjaga martabat anak (Abdullahi, 2017).

Sekolah dianggap "ramah anak" jika memperhatikan faktor perlindungan kesehatan dan menjaga keamanan anak. Sekolah menyediakan lingkungan yang aman, bersih, sehat dan protektif untuk anak-anak, hak-hak anak dihormati, dan semua anak termasuk anakanak yang miskin, cacat, berasal dari etnis dan agama minoritas diperlakukan sama (Çobanoğlu, Tuncel, \& Ordu, 2018). Sekolah juga harus menciptakan harmoni antara sekolah dengan masyarakat sekitar sehingga anak dapat belajar tentang norma dan interaksi sosial (Abdullahi, 2017). Maka sekolah ramah anak juga disebut sekolah berbasis masyarakat mengakui hak semua anak, terlepas dari gender, agama dan perbedaan etnis, status keluarga, kemampuan (Ekemezie \& Chinasa, 2015)

Berdasarkan uraian tersebut, maka implementasi pendidikan ramah anak di sekolah dapat dilakukan melalui beberapa hal diantaranya melalui kegiatan pembiasaan yang dilakukan secara rutin, keteladanan guru, proses pembelajaran yang menyenangkan, serta 
melalui bimbingan yang diberikan kepada anak didik(Risminawati \& Rofi'ah, 2015) sehingga membuat anak kerasan di sekolah dan belajar dengan tenang. Selain itu, anak juga akan tumbuh, berkembang, dan berpartisipasi dalam pendidikan secara wajar tanpa intimidasi kekerasan(Hajaroh, Rukiyati, Purwastuti, \& Saptono, 2017).

Sekolah yang ramah anak memiliki ciri inklusif, sehat dan protektif untuk semua anak, efektif dengan anak-anak, dan melibatkan keluarga dan masyarakat. Guru merupakan pendidik karakter yang tepat, terutama komponen karakter keadilan, tanggung jawab, sikap sukarela, dan keharmonisan kelompok. Komponen ini diinternalisasi dalam sistem sekolah sehingga menjadi budaya sekolah (Watz, 2011), meliputi dimensi moral feeling dengan pendekatan behavior action(Na'imah \& Pamujo, 2014). Manajemen sekolah ramah anak juga berkaitan dengan pengembangan konten kurikulum dan proses pembelajaran yang bermuatan nilai-nilai kehidupan (Abdullahi, 2017). Kebijakan yang perlu diambil oleh pihak sekolah yaitu kebijakan pengembangan program sekolah peduli, aman dan ramah. Selain itu perlu ada rekonstruksi program pembelajaran yang berbasis nilai-nilai (Makwarela, Mammen, \& Adu, 2017)

Internalisasi sebagai bagian dari proses pengembangan karakter, merupakan suatu pengaturan kedalam fikiran atau kepribadian, perbuatan nilai-nilai, patokan-patokan ide atau perilaku orang-orang lain menjadi bagian dari diri sendiri. Internalisasi merupakan proses atau cara menanamkan nilai-nilai normatif yang menentukan tingkah laku yang diinginkan bagi suatu sistem yang mendidik sesuai dengan tuntunan menuju terbentuknya kepribadian yang berkarakter. Internalisasi merupakan proses menanamkan keyakinan, sikap dan nilai yang dilakukan secara sengaja. Internalisasi nilai-nilai jika di lakukan sejak dini akan membentuk moral pada perkembangan selanjutnya (Emde, Biringen, Clyman, \& Oppenheim, 1991). Oleh karena itu penanaman nilai-nilai karakter bisa dilakukan dengan cara internalisasi dalam budaya, pembelajaran dan pembiasaan di sekolah.

Dengan demikian guru adalah kunci untuk membuat sekolah "ramah anak". Guru memiliki tanggungjawab menyampaikan pengetahuan dan kesadaran tentang hak anak kepada orang tua, anggota masyarakat, dan para siswa itu sendiri. Guru dianggap paling bisa memahami perkembangan anak, hal ini dianggap sebagai salah satu elemen terpenting dari Sekolah Ramah Anak, karena dengan memiliki informasi tersebut, guru menjadi lebih dekat dengan setiap anak didik dan memahami lebih jauh tentang kebutuhan atau masalah individu mereka.

Selain untuk memenuhi hak anak, maka sekolah ramah anak memiliki keunggulan untuk menyeimbangkan perlakuan pada anak dengan berbagai macam perbedaan (Çobanoğlu et al., 2018). Permasalahnnya adalah belum semua guru mampu menciptakan atmosfir sekolah yang ramah anak. Untuk itu perlu dilakukan penelitian yang mendalam tentang implementasi sekolah ramah anak di Taman Kanak-kanak sebagai dasar menyusun konsep sekolah ramah anak berbasis nilai-nilai karakter.

Berdasarkan hal itu maka tujuan penelitian ini adalah : 1) Mengeksplorasi implementasi sekolah ramah anak didik TK 'Aisyiyah di Purwokerto, 2) Mengembangkan konsep sekolah ramah anak berbasis nilai-nilai karakter.

\section{METODOLOGI}

Penelitian ini dirancang dengan menggunakan kualitatif dengan pendekatan grounded theory, yaitu metode penelitian kualitatif yang menggunakan sejumlah prosedur sistematis guna mengembangkan teori dari kancah melalui proses bertahap dan induktif (Denzim \& Lincoln, 1994).

Subjek penelitian dipilih karena keahlian atau kemampuannya dan keterlibatan dengan bidang pendidikan karakter dan program sekolah ramah anak. Oleh karena itu, dalam penelitian ini subjek penelitian adalah guru dan kepala sekolah taman kanak-kanak TK 'Aisyiyah 1 Purwokerto, TK 'Aisyiyah Teluk Purwokerto Selatan dan TK Bantarwuni, Sumbang. 
Dalam proses kerja pengumpulan data penelitian dilakukan selama 1 semester dengan menggunakan 2 (dua) metode utama yang digunakan secara simultan, yaitu observasi dan wawancara mendalam (depthinterview). Observasi dan wawancara dilakukan sebelum dan selama proses penelitian yang meliputi gambaran umum, suasana kehidupan sosial di Taman kanak-kanak.Selama wawancara, peneliti mengamati bahasa tubuh, nada suara dan intensitas emosional. Peneliti memasukkan hasil pengamatan tersebut dalam transkrip hasil wawancara.

Adapun instrumen utama untuk pengumpulan data dalam penelitian grounded theory ini adalah peneliti sendiri, sedangkan instrumen pendukungnya adalah panduan observasi dan panduan wawancara.

Teknik analisis data dalam penelitian grounded-theory ini adalah teknik analisis komparatif konstan (Constant Comparative Analysis). Dalam penelitian ini peneliti membandingkan kejadian yang dapat diterapkan pada tiap kategori, dan memadukan kategori-kategori serta ciri-cirinya, membatasi lingkup teori dan diakhiri dengan menulis teori (Thi Thanh Thai, Choy Chong, \& Agrawal, 2012).

Ada tiga proses dalam Constant Comparative Analysis yaitu pengkodean terbuka, pengkodean aksial dan pengkodean selektif (Thi Thanh Thai et al., 2012). Pengkodean terbuka yang digunakan untuk mengidentifikasi kategori utama dari isi data Proses kedua adalah pengkodean aksial, yaitu identifikasi sifat-sifat spesifik dari kategori dimensi yang dibentuk kembali dari data yang telah dipisahkan dari pengkodean terbuka, Proses ketiga yaitu pengodean selektif untuk menemukan titik utama untuk menjawab pertanyaan penelitian. Proses penelitian digambarkan sebagai berikut :

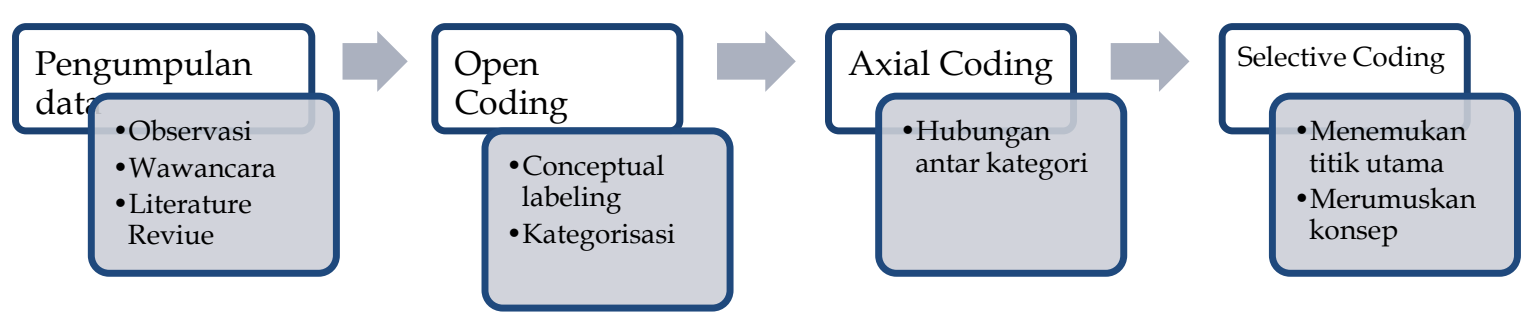

Gambar 1. Proses penelitian

\section{HASIL DAN PEMBAHASAN}

\section{Data demografi}

Subjek penelitian ini dapat digambarkan dalam tabel 1.

Tabel 1. Data Demografi

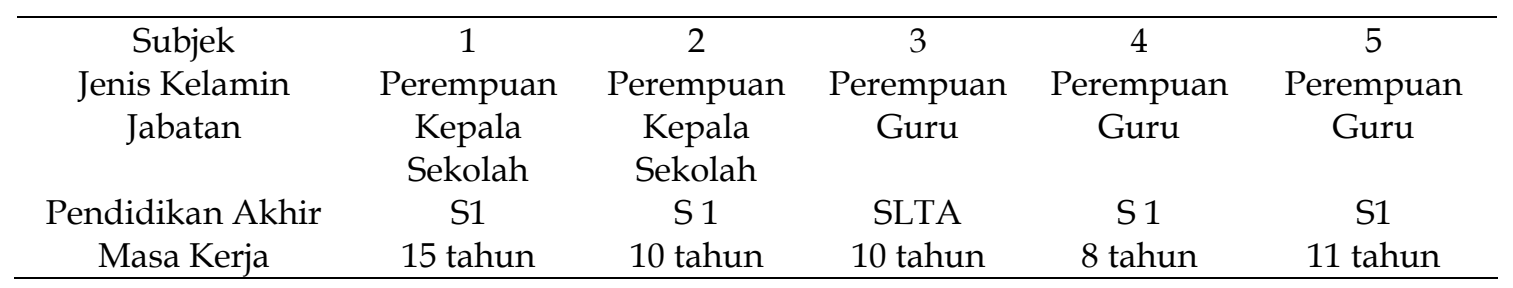

Tabel tersebut menggambarkan data demografi subjek penelitian. Semua subjek berjenis kelamin perempuan dengan jabatan kepala sekolah dan guru kelas Taman kanakkanak. Rentang masa kerja subjek penelitian antara 8-15 tahun, hanya satu subjek penelitan yang berpendidikan SLTA. 
Data tersebut menunjukkan bahwa subjek penelitian memiliki masa kerja diatas 5 tahun, sehingga memiliki pengalaman mengelola pendidikan taman kanak-kanak. Latar belakang pendidikan sebagian besar sarjana pendidikan anak usia dini, sehingga secara akademik memahami seluk beluk pendidikan anak usia dini. Hal ini juga diasumsikan bahwa subjek memiliki kompetensi profesional dan kompetensi paedagogik. Peneliti memilih subjek didasarkan pada kualifikasinya sebagai pengelola pendidikan anak usia dini, sebagai dasar untuk merumuskan konsep sekolah ramah anak.

\section{Open Coding}

Peneliti melakukan proses pengkodean terbuka dari data yang diperoleh dan mengidentifikasi tigakategori dengan 5 sub kategori yang berkaitan dengan implementasi sekolah ramah anak di Taman Kanak-kanak untuk mengembangkan karakter anak. Gambar1 menunjukkan kategoridan sub kategori yang diperoleh dari pengkodean terbuka.

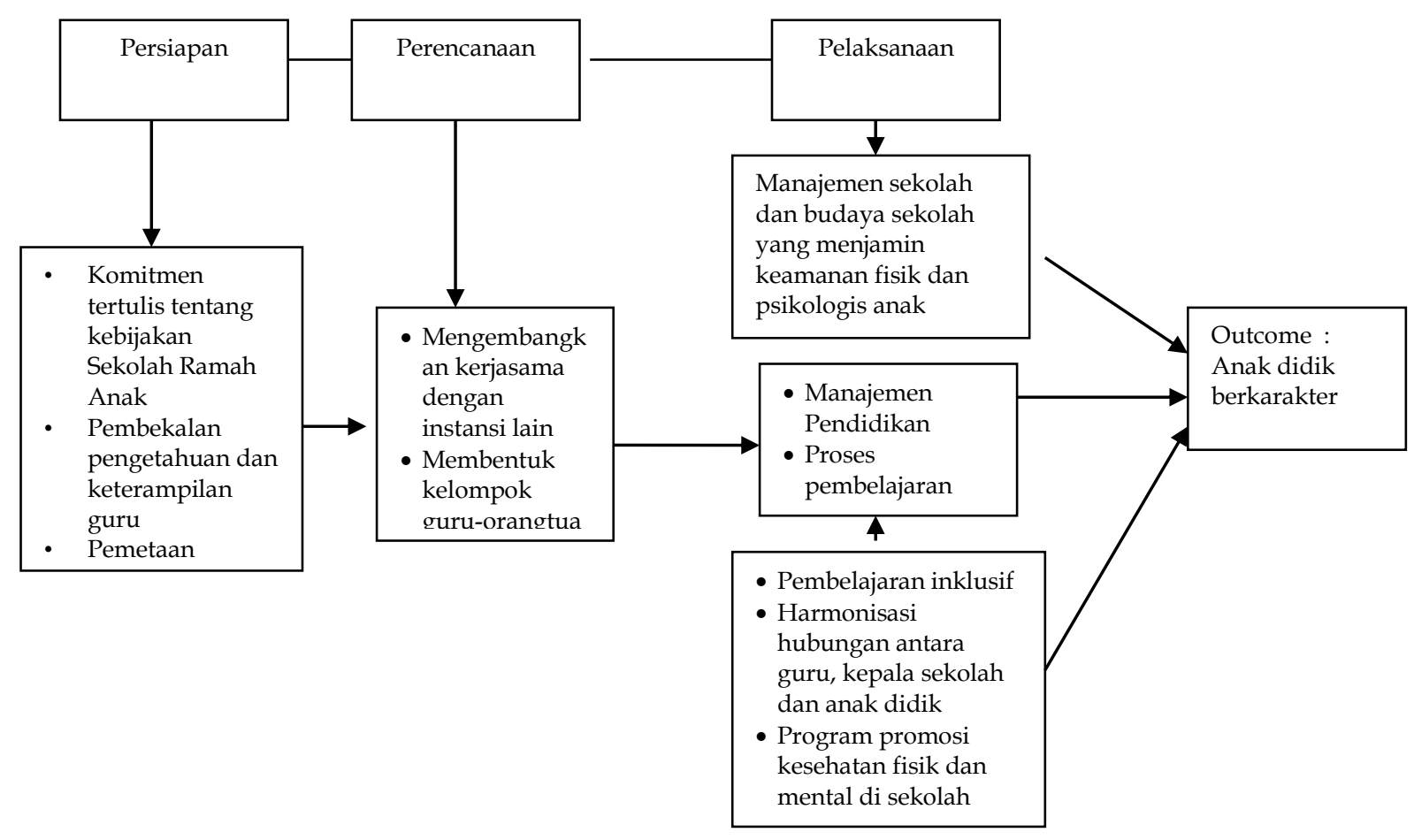

\section{Axial Coding}

\section{Gambar 2. Hasil Open Coding}

Berdasarkan axial coding maka peneliti memfocuskan pada tiga kategori yang berkaitan dengan implikasi sekolah ramah anak, yaitu tahap persiapan, tahap perencanaan dan tahap pelaksanaan. Temuan penelitian diuraikan berikut ini :

\section{Kategori persiapan implikasi sekolah ramah anak}

Semua informan mengatakan tidak ada persiapan khusus untuk mewujudkan sekolah ramah anak. Ketiga informan belum pernah mengikuti pelatihan khusus tentang implementasi sekolah ramah anak, tetapi beberapa guru pernah mengikuti sosialisasi tentang sekolah ramah anak. Oleh karena itu pengetahuan guru tentang sekolah ramah anak berbeda-beda. Informan mengatakan bahwa sekolah ramah anak adalah : 1) Sekolah yang

bisa membuat anak senang dan tidak takut bersekolah, 2) Sekolah yang dapat menerima anak sesuai tahap perkembangannya, 3) Sekolah yang melayani anak, membuat nyaman dan tidak memaksa anak. 
Semua informan mengatakan tidak ada persiapan khusus untuk mewujudkan sekolah ramah anak. Program sekolah ramah anak diintegrasikan dengan program sekolah yang ada, yaitu program rutin parenting, out class program, program kesehatan sekolah.

Sekolah tidak melakukan pemetaan kebutuhan siswa secara khusus, tetapi menerima anak berkebutuhan khusus dengan rekomendasi psikolog. Informan menyatakan tidak menerapkan kurikulum sekolah inklusi. Program penanganan masalah anak dilakukan oleh guru yang berpengalaman, tidak ada kerjasama khusus dengan pihak lain dalam konseling untuk gangguan perilaku anak.

Kepala sekolah tidak membuat kebijakan khusus tentang sekolah ramah anak, tetapi semua program pendidikan diarahkan kepada layanan anak. Perencanaan program sekolah ramah anak belum masuk secara khusus dalam rencana anggaran sekolah, tetapi terintegrasi dalam kegiatan rutin sekolah.

Hasil penelitian ini menunjukkan bahwa belum ada kesiapan khusus dalam bentuk komitmen tertulis untuk menciptakan sekolah ramah anak. Sekolah belum memiliki surat keputusan tentang kebijakan sekolah ramah anak, ataupun SK Tim pengembang sekolah ramah anak dan SK tim pelaksana sekolah ramah anak. Tetapi sekolah memiliki komitmen untuk menuju sekolah ramah anak dalam bentuk internalisasi nilai-nilai sekolah ramah anak dalam kurikulum dan program sekolah. Sekolah sudah mengembangkan atmosfir sekolah aman/bersih dan sehat/peduli dan berbudaya lingkungan hidup. Filosofi pendidikan ramah anak ditekankan pada program pendidikan berbasis partisipasi anak (Abdullahi, 2017).

\section{Kategori perencanaan sekolah ramah anak}

Sekolah menyelenggarakan program kerjasama dengan pihak lain untuk pengembangan program pendidikan, yaitu dengan persatuan orangtua wali siswa, Dikdasmen 'Aisyiyah Banyumas, Universitas Muhammadiyah Purwokerto, dan Puskesmas. Bentuk kerjasama tersebut adalah penyelenggaraan program pembelajaran, pembinaan guru, pembinaan kesehatan lingkungan dan kesehatan anak.

Partisipasi pihak-pihak luar dalam kegiatan sekolah merupakan wujud dari persiapan menuju sekolah ramah anak. Komunikasi intens antara guru dan orangtua diwujudkan dalam group whatshap wali siswa. Di ketiga sekolah belum ditemukan sistem rujukan untuk mengatasi masalah-masalah pendidikan.

Walaupun kondisi sekolah masih seperti ini, tetapi kesadaran untuk membangun sekolah yang ramah anak sudah dimulai. Konsep sekolah ramah anak bukanlah blue print yang bersifat kaku, sehingga sekolah bisa merubah karakteristik sekolah ramah anak sesuai dengan kondisi sosial ekonomi, kondisi sekolah agar terjadi kesinambungan arah (Çobanoğlu et al., 2018).

\section{Kategori pelaksanaan sekolah ramah anak}

Untuk melaksanakan program pembelajaran berbasis hak anak, guru membuat rencana pembelajaran yang disesuaikan dengan kurikulum dengan metode pembelajaran sesuai dengan perkembangan anak. Guru memadukan antara metode in class dan out class, mengintegrasikan kegiatan belajar dan bermain.

Pemeliharaan kebersihan lingkungan melibatkan guru, tenaga kebersihan dan anak didik. Sekolah menyediakan fasilitas kamar mandi dan tempat wudlu walaupun belum permanen. Tempat sampah disediakan di setiap kelas, tetapi belum dipisahkan antara sampah plastik dan non plastik.

Guru mengintegrasikan pendidikan kesehatan dalam kegiatan pembelajaran dalam bentuk : 1) Mengajarkan anak masalah kebersihan dan kesehatan, 2) Memberikan penjelasan untuk tetap menjaga kebersihan tempat dan diri sendiri, misalnya membuang sampah, cuci tangan setelah buang air, 3) Praktek mencuci tangan sebelum makan, 4) integrasi olahraga, belajar dan bermain. 
Temuan tersebut menunjukkan bahwa sekolah sudah mengintegrasikan nilai-nilai sekolah ramah anak dalam proses pembelajaran. Di ketiga sekolah juga belum ditemukan mekanisme pengaduan jika ditemukan masalah gangguan perilaku siswa, masalah kekerasan anak, maupun masalah pendidikan lainnya. Idealnya sekolah ramah anak memperhatikan kesehatan fisik dan mental anak, sehingga sekolah bebas hukuman fisik dan dilengkapi layanan konseling (Çobanoğlu et al., 2018).

Peneliti juga menemukan karakter anak yang perlu dioptimalisasi lagi adalah karakter kreatif, toleransi dan cinta damai, kepemimpinan. Prosentasi terbesar dalam kategori BB (belum berkembang), artinya anak dapat melakukan tetapi harus dengan bimbingan dan contoh dari guru. Guru perlu mengembangkan lingkungan belajar yang dapat memotivasi anak-anak untuk berkreasi, mengembangkan sikap ramah, peduli dan memperhatikan kesehatan, interaksi sosial dan masalah keamanan emosional anak-anak (Abdullahi, 2017).

Sekolah ramah anak adalah konsep yang berkaitan dengan beberapa aspek, seperti kondisi fisik sekolah, kesehatan lingkungan, proses belajar-mengajar, sumber dan materi pembelajaran, guru, kepala sekolah, kesehatan, keamanan, partisipasi orangtua dan isntansi lain dan sensitivitas gender. Semakin lengkap aspek itu terpenuhi maka sekolah dikategorisasikan sekolah ramah anak. Model sekolah ramah anak bukanlah konsep yang kaku, setiap sekolah secara fleksibel dapat menyusun program sesuai dengan kondisi sekolah, yang dapat meningkatkan progres pemenuhan hak anak (Ekemezie \& Chinasa, 2015).

Temuan penelitian menunjukkan bahwa belum ada komitmen tertulis tentang sekolah ramah anak, tetapi dalam pelaksanaan pendidikan sudah mengintegrasikan prinsipprinsip sekolah ramah anak. Prinsip utama dalam sekolah ramah anak adalah sekolah menghargai perbedaan tumbuh kembang anak dan bertanggungjawab menerima semua perbedaan yang ada pada anak (Çobanoğlu,Tuncel, dan Ordu, 2018). Guru dapat menciptakan harmoni di sekolah dengan menciptakan suasana kelas penuh loving, kasih sayang, saling menghormati, membiasakan komunikasi yang baik antar guru dengan anak didik (Na'imah \& Dwiyanti, 2015).

Semua guru juga menginternalisasi prinsip-prinsip sekolah ramah anak dalam setiap kegiatan pembelajaran, menerapkan prinsip-prinsip paedagogik yang berbasis kebutuhan anak. Tetapi hal ini tidak menjamin bahwa sekolah sudah termasuk kategori sekolah ramah anak, karena dimensi lain juga harus diperhatikan guru, antara lain menjaga keamanan lingkungan sekolah (Osher, et, all, 2009).

Temuan penelitian juga menunjukkan bahwa sekolah tidak memiliki program khusus untuk mendampingi masalah anak. Sekolah juga tidak memiliki mekanisme pengaduan gangguan anak. Dimensi sekolah ramah anak yang penting adalah strategi mengatasi masalah anak baik akademik maupun non akademik. Anak berhak mendapatkan layanan pendidikan sesuai standar pendidikan yang berlaku. Dalam hal ini termasuk layanan kesehatan bagi anak. Peneliti tidak menemukan informasi layanan kesehatan ecara rutin, walaupun sekolah sudah memiliki kerjasama dengan Puskesmas. Layanan kesehatan dilakukan secara insidental, sesuai kebutuhan sekolah. Menjadi sehat bukan hanya berarti tidak sakit secara fisik, tetapi juga sehat psikologis dan tercapainya kesejahteraan sosial. Kesehatan sekolah meliputi layanan dan strategi di sekolah yang diimplementasikan untuk mendukung kesehatan fisik, perkembangan psikologis dan sosial siswa. Özcebe (dikutip Çobanoğlu et al., 2018) menyatakan bahwa ada hubungan linier antara kesehatan anak dan efisiensi anak lembaga dan penurunan keberhasilan akademik. Dengan demikian layanan kesehatan fisik, psikologis dan sosial secara terpadu penting untuk diberikan untuk anak usia dini.

Temuan penelitian menunjukkan karakter kreatif, toleransi dan cinta damai, kepemimpinan belum berkembang dengan baik, yang ditunjukkan dengan kategori BB (belum berkembang). Dalam evaluasi pembelajaran di taman kanak-kanak, kategori 'belum 
berkembang' dapat dimaknai bahwa anak masih membutuhkan bimbingan dan pemberian contoh langsung dari guru. Oleh karena itu guru harus bisa menjadi model bagi anak didik. Untuk meningkatkan kreatifitas anak didik guru dapat meningkatkan dimensi being pada anak, yaitu stimulasi untuk bebas berkarya, atau pembelajaran kreatif thinking. Sedangkan untuk menstimulasi karakter toleransi, cinta damai dan kepemimpinan guru dapat mengoptimalkan dimensi loving, yaitu suasana penuh kasih sayang di sekolah (Na'imah \& Dwiyanti, 2015). Guru juga dapat mengintegrasikan optimalisasi karakter tersebut dalam proses pendidikan. Informan mengatakan selalu memberikan pendidikan karakter secara tidak langsung kepada anak didik, begitu juga pembiasaan hidup sehat dilakukan dalam kegiatan pembelajaran dan di luar jam pembelajaran. Untuk meningkatkan proses pembelajaran yang berkualitas baik dapat dilakukan dengan pendekatan individual yang sesuai dengan tingkat perkembangan setiap anak, penggunaan metode pembelajaran kooperatif dan demokratis (Godfrey et al., 2012)

\section{Pengodean selektif}

Yaitu menemukan titik utama untuk menjawab pertanyaan penelitian. Temuan penelitian yang sudah terkategorisasikan dihubung-hubungkan untuk menemukan kategori sentral. Setelah melakukan pengkodean selektif maka dihasilkan taksonomi sekolah ramah anak untuk membangun karakter anak didik. Taksonomi implikasi sekolah ramah anak di TK dijabarkan dalam tabel 2 :

Tabel 2. Taksonomi Implementasi Sekolah Ramah Anak di TK

\begin{tabular}{ll}
\hline \multicolumn{1}{c}{ Indikator } & \multicolumn{1}{c}{ Deskripsi } \\
\hline $\begin{array}{l}\text { school-based character } \\
\text { education }\end{array}$ & $\begin{array}{l}\text { Pendidikan karakter berbasis sekolah bertujuan untuk mencegah } \\
\text { terjadinya perilaku kekerasan. Pendidikan bermuatan penguatan } \\
\text { akdemik dan penguatan perilaku, misalnya interaksi sosial antara } \\
\text { siswa dengan sesama dan dengan guru sehingga menciptakan budaya } \\
\text { sekolah yang lebih peduli dan harmonis. Anak didik diberi } \\
\text { kesempatan mempraktikkan berbagai tindakan seperti kebaikan, } \\
\text { kejujuran, dan tanggung jawab yang diilhami oleh teman dan guru }\end{array}$ \\
\hline safe school environment & $\begin{array}{l}\text { Lingkungan sekolah yang memberi rasa aman dan nyaman, bebas dari } \\
\text { rasa takut saat anak belajar. }\end{array}$ \\
\hline friendly schools & $\begin{array}{l}\text { Sekolah yang ramah anak memastikan setiap anak memiliki } \\
\text { lingkungan yang aman secara fisik, aman secara emosional dan secara }\end{array}$ \\
\hline psikologis. & Inklusivitas artinya bahwa semua anak memiliki hak atas pendidikan \\
& dan akses ke pendidikan. Kebijakan dan layanan pendidikan \\
& mendukung keadilan, non-diskriminasi dan partisipatif. \\
\hline religious schools & Pengembangan karakter berbasis pendidikan agama \\
\hline
\end{tabular}

Taksonomi ini menunjukkan bahwa pengembangan karakter anak dapat dilakukan dengan mengembangkan manajemen sekolah dan budaya sekolah yang menjamin keamanan fisik dan psikologis anak. Implikasi pembelajaran ramah anak adalah dengan menerapkan pembelajaran inklusif, pembelajaran ramah lingkungan, pendidikan sosial, pendidikan berbasis keadilan dan pendidikan berbasis agama.

Konsep sekolah ramah anak ini menggunakan pendekatan komprehensif yang menghubungkan semua aspek reformasi dalam pendidikan dan yang menempatkan anak sebagai pusat alternatif dalam semua kegiatan sekolah (Abdullahi, 2017). Konsep ini merupakan konsep yang multidimensional untuk menuju sekolah berkualitas.

Penelitian ini memiliki beberapa keterbatasan, antara lain kurang beragamnya informan penelitian. Oleh karena itu disarankan untuk penelitian yang akan datang dapat melakukan penelitian kebijakan sekolah ramah anak dengan pendekatan kuantitatif dan kualitatif yang lebih mendalam. 


\section{SIMPULAN}

Konsep sekolah ramah anak untuk pengembangan karakter anak usia dini terdiri dari dimensi persiapan, perencanaan, pelaksanaan dan output. Untuk melaksanakan program sekolah ramah anak perlu diawali dengan persiapan, yaitu komitmen tertulis berupa aturan atau surat keputusan tentang pelaksanaan sekolah ramah anak. Komitmen ini menjadi dasar guru dan kepala sekolah melaksanakan program pendidikan yang berbasis kebutuhan anak.Optimalisasi karakter anak dapat dilakukan dengan mengembangkan manajemen sekolah dan budaya sekolah yang menjamin keamanan fisik dan psikologis anak. Implikasi pembelajaran ramah anak adalah dengan menerapkan pembelajaran inklusif, menjaga harmonisasi hubungan antara guru, kepala sekolah dan anak didik, menyelenggarakan program promosi kesehatan fisik dan mental di sekolah serta pendidikan karakter.

\section{UCAPAN TERIMAKASIH}

Penulis ucapkan banyak terimakasih kepada Lembaga Penelitian dan Pengabdian pada Masyarakat Universitas Muhammadiyah Purwokerto, Jawa Tengah atas pemberian dana dalam program hibah penelitian skim Penelitian Fundamental.

\section{DAFTAR PUSTAKA}

Abdullahi, H. U. (2017). Child Friendly Schools in Nigeria the Role of the Teacher. International Journal of Education and Evaluation, 3(6), 7-12.

Abu, L., Mokhtar, M., Hassan, Z., \& Darmanita Suhan, S. Z. (2015). How to Develop Character Education of Madrassa Students in Indonesia. Journal of Education and Learning (EduLearn), 9(1), 79. https:// doi.org/10.11591/edulearn.v9i1.768

Çobanoğlu, F., Tuncel, Z. A.-, \& Ordu, A. (2018). Child-friendly Schools : An Assessment of Secondary Schools. Universal Journal of Educational Research, 6(3), 466-477. https:// doi.org/10.13189/ujer.2018.060313

Denzin, N. K., \& Lincoln, Y. S. (2002). The qualitative inquiry reader. Sage.

Ekemezie, C. A., \& Chinasa, S. (2015). Child Friendly Pedagogy for Sustainable Human Capacity Development in Nigerian Primary Schools. Journal of Emerging Trends in Educational Research and Policy Studies, 6(7), 217-224.

Emde, R. N., Biringen, Z., Clyman, R. B., \& Oppenheim, D. (1991). The moral self of infancy: Affective core and procedural knowledge. Developmental Review, 11(3), 251-270. https:// doi.org/10.1016/0273-2297(91)90013-E

Godfrey, E. B., Osher, D., Williams, L. D., Wolf, S., Berg, J. K., Torrente, C., ... Aber, J. L. (2012). Children and Youth Services Review Cross-national measurement of school learning environments : Creating indicators for evaluating UNICEF' s Child Friendly Schools Initiative tr. Children and Youth Services Review, 34(3), 546-557. https://doi.org/10.1016/j.childyouth.2011.10.015

Hajaroh, M., Rukiyati, Purwastuti, L. A., \& Saptono, B. (2017). Analisis Kebijakan Sekolah Ramah Anak di Kawasan Pesisir Wisata. Yogyakarta: Penerbit Andi.

Iswantiningtyas, V., \& Wulansari, W. (2019). Penanaman Pendidikan Karakter pada Model Pembelajaran BCCT (Beyond Centers and Circle Time). Jurnal Obsesi : Jurnal Pendidikan Anak Usia Dini, 3(1), 110. https:/ / doi.org/10.31004/obsesi.v3i1.106

Juanda, J. (2019). Pendidikan Karakter Anak Usia Dini melalui Sastra Klasik Fabel Versi Daring. Jurnal Obsesi: Jurnal Pendidikan Anak Usia Dini, 3(1), 39. https://doi.org/10.31004/obsesi.v3i1.126

Makwarela, M. C., Mammen, K. J., \& Adu, E. O. (2017). An Assessment of the Implementation of DoE and UNICEF Guidelines for Creating Safe, Caring and Childfriendly Schools: A South African Case Study An Assessment of the Implementation of DoE and UNICEF Guidelines for Creating Safe, Caring and Child-frien. Journal of Social Sciences, 50(1), 1-7. https://doi.org/10.1080/09718923.2017.1311720 
Na'imah, T., \& Dwiyanti, R. (2015). the Implications of School Well Being Model As Banyumasan Character. Asia Pasific Journal of Research, 1(XXX), 55-61.

Na'imah, T., \& Pamujo. (2014). School well being pada anak didik di taman kanak- kanak. Sainteks, XI(2), 1-5.

Nata, A. (2010). Menejemen Pendidikan Mengatasi Kelemahan Pendidikan Islam di Indonesia (edisi 3). Jakarta: Prenada Media Group.

Risminawati, \& Rofi'ah, S. N. (2015). Implementasi Pendidikan Ramah Anak dalam Pembentukan Karakter Siswa Kelas Rendah SD Muhammadiyah Program Khusus Kotta Barat Tahun Pelajaran 2013/ 2014. Profesi Pendidkan Dasar, 2(1), 9.

Thi Thanh Thai, M., Choy Chong, L., \& Agrawal, N. M. (2012). The Qualitative Report Straussian Grounded-Theory Method: An Illustration. The Qualitative Report, 17(52), $1-$ 55. Retrieved from https:/ / nsuworks.nova.edu/tqr/vol17/iss26/2

Watz, M. (2011). An Historical Analysis of Character Education. Journal of Inquiry \& Action in Education, 4(2), 34-53. 